Volume 5 Nomor 1, Februari 2020, halaman 61-76

\title{
ANALISIS TERHADAP DISPOSISI BERPIKIR KRITIS SISWA JURUSAN IPS PADA PEMBELAJARAN MATEMATIKA
}

\section{ANALYSIS OF CRITICAL THINKING DISPOSITION OF IPS STUDENTS IN MATHEMATICS LEARNING}

\author{
Eline Yanty Putri Nasution ${ }^{1}$, Devi Pebrianti ${ }^{2}$, Rahmi Putri ${ }^{3}$ \\ ${ }^{1}$ Institut Agama Islam Negeri Kerinci, Jl. Kapten Muradi Desa Sumur Gedang Kec. Pesisir Bukit \\ Kota Sungai Penuh Provinsi Jambi, elineyantyputrinasution@iainkerinci.ac.id \\ ${ }^{2}$ Institut Agama Islam Negeri Kerinci, Jl. Kapten Muradi Desa Sumur Gedang Kec. Pesisir Bukit \\ Kota Sungai Penuh Provinsi Jambi, DeviPebrianti1122@gamil.com. \\ ${ }^{3} 1$ Institut Agama Islam Negeri Kerinci, Jl. Kapten Muradi Desa Sumur Gedang Kec. Pesisir Bukit \\ Kota Sungai Penuh Provinsi Jambi, rahmiputri@iainkerinci.ac.id
}

\begin{abstract}
ABSTRAK
Penelitian ini bertujuan untuk menganalisis keadaan disposisi berpikir kritis siswa, faktor-faktor apa saja yang berpengaruh terhadap disposisi berpikir kritis siswa, serta solusi untuk meningkatkan disposisi berpikir kritis siswa pada pembelajaran matematika di kelas XI IPS pada salah satu SMA di Kota Sungai Penuh Provinsi Jambi. Penelitian ini merupakan penelitian kualitatif menggunakan pendekatan deskriptif dengan jenis penelitian lapangan. Objek penelitian ini adalah seluruh siswa Kelas XI IPS 1 SMAN 5 yang berjumlah 23 orang dengan 1 orang Guru Matematika sebagai informan penelitian. Penelitian ini menggunakan instrumen Angket (Kuesioner) Disposisi Berpikir Kritis, Pedoman Wawancara untuk Guru dan Siswa, serta Lembar Observasi Aktivitas Guru dan Siswa. Berdasarkan hasil analisis data diperoleh bahwa: 1) terdapat 5 orang siswa (22\%) memiliki disposisi berpikir kritis yang tinggi; 2) terdapat 13 orang siswa (56\%) memiliki disposisi berpikir kritis yang sedang; dan 3) terdapat 5 orang siswa (22\%) memiliki disposisi berpikir kritis yang rendah. Rendahnya disposisi berpikir kritis siswa IPS dapat ditanggulangi dengan memberikan strategi pembelajaran yang dapat meningkatkan disposisi berpikir kritis siswa IPS dalam pembelajaran matematika.
\end{abstract}

Kata Kunci: disposisi, berpikir kritis, kualitatif, deskriptif, siswa IPS

\section{ABSTRACT}

This study aim to analyze the condition of students' critical thinking disposition, all factors that affected students' critical thinking disposition, and the solution to improve students' critical thinking disposition in mathematics learning at XI IPS grade in one of SMA in Sungai Penuh City, Jambi Province. This study is a qualitative research using descriptive approach with field research type. The object of this study is all of XI IPS 1 SMAN 5 students that contain 23 students with 1 mathematics teacher as the research informer. This study use critical thinking disposition questionnaire, interview guidelines for teacher and students then observation sheet for teacher and student's activity instruments. According to the data analysis result, obtain that: 1) there are 5 students (22\%) has higher critical thinking disposition; 2) there are 13 students (56\%) has medium critical thinking disposition; and 3) there are 5 students (22\%) has lower critical thinking disposition. The lowerness of IPS students' critical thinking disposition can be solved by applicate learning strategies that can improve IPS students' critical thinking disposition in learning mathematics.

Keywords: disposition, critical thinking, qualitative, descriptive, IPS students 
How to Cite: Nasution, E. Y. P, Pebrianti, D., Putri, R. (2020). Analisis Terhadap Disposisi Berpikir Kritis Siswa Jurusan IPS Pada Pembelajaran Matematika. Mathline: Jurnal Matematika dan Pendidikan Matematika, Vol.5 No.1, 61-76

DOI: $\underline{\text { https://doi.org/10.31943/mathline.v5i1.130 }}$

\section{PENDAHULUAN}

Pendidikan merupakan suatu proses pembentukan kemampuan fundamental yang berkaitan dengan intelektual (daya pikir) maupun emosional (daya perasaan) sesuai tabiat manusia sebagai manusia biasa (Arifin, 2010). Menurut UU No. 20 Tahun 2003 tentang Sisdiknas, pendidikan bertujuan agar peserta didik mampu mengembangkan potensi dirinya secara aktif sehingga memiliki kekuatan spiritual atau keagamaan, pengendalian diri, kepribadian, kecerdasan, akhlak mulia, serta keterampilan yang diperlukan bagi dirinya, masyarakat, bangsa, dan negara melalui suatu usaha sadar dan terencana dalam mewujudkan suasana dan proses belajar dan pembelajaran (Hamdani, 2011). Oleh sebab itu, kegiatan pendidikan harus sadar dengan tujuan akhir yang hendak dicapai. Tujuan akhir proses pendidikan tersebut merupakan bagian yang sangat penting untuk dicapai melalui proses pendidikan (Jalaluddin \& Abdullah, 2010).

Dalam upaya pencapaian tujuan pendidikan, pelaksanaan proses pembelajaran harus berdasarkan dengan perencanaan yang matang, sehingga dihasilkan tujuan akhir pembelajaran yang diharapkan pada semua mata pelajaran, termasuk mata pelajaran matematika. Matematika merupakan ratu ilmu pengetahuan yang selalu berkaitan dengan bidang ilmu lainnya. Matematika yang memiliki kedudukan sebagai ratu ilmu pengetahuan tetapi juga merupakan pelayan bagi ilmu pengetahuan lain (Suherman, 2003). Matematika merupakan pola pikir rasional dan logis memiliki peranan yang sangat penting dalam mengembangkan kemampuan berpikir tingkat tinggi (high order thinking skill) pada siswa. Pola pikir matematis yang dimiliki siswa akan sangat bermanfaat di dalam kehidupan seharihari karena matematika berkaitan dengan pengembangan penalaran logis. Dapat disimpulkan bahwa matematika tidak hanya bermanfaat di bidang matematika saja tetapi juga pada bidang lainnya seperti bidang Ilmu Pengetahuan Sosial (IPS).

Secara ontologi, siswa jurusan IPS diduga tidak memiliki ketertarikan pada Matematika. Hal ini didasarkan pada observasi awal penulis yang menghasilkan bahwa 
alasan dari kebanyakan siswa dalam mengambil jurusan IPS adalah karena ingin menghindari Matematika. Wawancara penulis terhadap guru matematika pada siswa jurusan IPS menghasilkan suatu kesimpulan yaitu siswa jurusan IPS cenderung tidak semangat dan tidak berminat saat belajar matematika. Hal tersebut didukung oleh pernyataan Susanti \& Rohmah (2012) yaitu siswa IPS mengalami kecemasan matematika sehingga matematika merupakan mata pelajaran yang paling banyak dipilih untuk diulang oleh siswa tersebut. Kenyataan tersebut mengindikasikan bahwa disposisi matematis siswa jurusan IPS rendah. Nasution (2016) menyatakan bahwa kebanyakan siswa masih kurang percaya diri dan enggan dalam menyatakan pendapatnya di depan kelas, siswa juga kurang berkonsentrasi dan kurang bisa bekerja sama dalam diskusi kelompok. Hal tersebut merupakan beberapa permasalahan yang dialami siswa yang memiliki disposisi matematis yang negatif selama mengikuti pembelajaran matematika.

Disposisi didefinisikan sebagai kebiasaan dengan sadar, teratur dan ikhlas dalam bertindak untuk mencapai suatu tujuan tertentu. Disposisi matematis adalah sudut pandang siswa dalam upaya penyelesaian masalah dengan percaya diri, tekun, dan semangat secara open-minded dengan mengelaborasi berbagai alternatif penyelesaian masalah yang mungkin (Yunarti, 2011). Disposisi juga berhubungan dengan kebiasaan siswa untuk merefleksikan diri terkait hasil kegiatan berpikir mereka sendiri, baik dalam bermatematika maupun dalam kehidupan. Jadi secara epistemologi, disposisi matematis sangat penting untuk ditumbuhkembangkan pada siswa, tidak terkecuali pada siswa jurusan IPS.

Dugaan rendahnya disposisi matematis siswa IPS yang diperkuat berdasarkan hasil pengamatan penulis saat observasi awal, yaitu beberapa siswa IPS pasif selama proses pembelajaran matematika sedang berlangsung. Kebanyakan siswa terlihat tidak fokus dan tidak percaya diri saat belajar Matematika. Hal ini didukung oleh pernyataan Nasution (2018) yaitu Matematika merupakan salah satu materi yang sulit dan tidak diminati oleh siswa. Rendahnya disposisi matematis siswa juga terjadi pada siswa SMA di daerah lain, seperti di Cimahi-Jawa Barat (Chotimah, Bernard, \& Wulandari, 2018). Lemahnya disposisi matematis siswa IPS juga diperoleh dari hasil wawancara terhadap guru Matematika yang menyatakan bahwa sebagian besar siswa tidak berminat belajar Matematika. Hal tersebut tampak berdasarkan sikap siswa yang kurang semangat dalam menyelesaikan permasalahan yang diberikan guru dan siswa enggan untuk bertanya jika ada yang kurang dimengerti. Siswa tampak kurang berusaha untuk memahami pelajaran yang sedang dibahas sehingga prestasi belajar Matematika siswa rendah. 
Sementara itu, disposisi matematis siswa sangat penting dalam menentukan keberhasilan belajar siswa. Salah satu faktor utama dalam menunjang keberhasilan belajar siswa adalah disposisi matematis (Mahmudi \& Saputro, 2016). Beberapa indikator disposisi matematis siswa adalah percaya diri dalam meyelesaikan tugas, berkomunikasi matematik, rasa ingin tahu yang tinggi, dan lain-lain (Ismunandar, 2016). Rendahnya disposisi matematis siswa mengindikasikan rendahnya disposisi siswa terhadap kemampuan berpikir matematis, seperti berpikir kritis.

Disposisi berpikir kritis adalah suatu kebiasaan atau sikap yang tampak dan melekat dalam diri seseorang dengan bertindak secara kritis pada saat berpikir sehingga dapat dijabarkan, dievaluasi, dan dibandingkan oleh dirinya sendiri maupun orang lain (Nopriana, 2015). Disposisi berpikir kritis siswa yang rendah akan berakibat kepada kemampuan berpikir kritis yang tidak maksimal. Ennis (Ulger, 2018) menyatakan bahwa disposisi berpikir kritis menunjukkan adanya kemampuan berpikir kritis. Tümkaya, Aybek, \& Aldaş (2009) juga menyatakan bahwa adanya disposisi berpikir kritis mampu mengembangkan kemampuan kognitifnya, yaitu kemampuan berpikir kritis. Kemampuan berpikir kritis merupakan salah satu keahlian berpikir tingkat tinggi yang tentu saja sangat berguna jika dimiliki oleh siswa, begitu pula siswa jurusan IPS.

Jika seseorang memiliki kemampuan berpikir secara kritis, maka akan muncul suatu disposisi dalam kegiatan berpikir tersebut yang dicirikan dengan: bertanya dengan jelas dan beralasan, berusaha memiliki pemahaman yang baik, menggunakan sumber yang relevan, mempertimbangkan situasi secara keseluruhan, berusaha tetap mengacu pada masalah pokok yang relevan, mencari banyak alternatif penyelesaian, open-minded, berani mengambil keputusan, bertindak cepat, percaya bahwa sesuatu adalah bagian dari keseluruhan yang kompleks, memanfaatkan cara berpikir kritis orang lain, dan bersikap sensitif terhadap perasaan orang lain (Hendriana, Sumarmo \& Rohaeti, 2013). Oleh sebab itu secara teori, disposisi berpikir kritis mampu memberikan dampak yang sangat baik untuk siswa, begitu juga untuk siswa jurusan IPS. Dengan demikian, penelitian ini bertujuan untuk menganalisis keadaan disposisi berpikir kritis siswa, faktor-faktor apa saja yang berpengaruh terhadap disposisi berpikir kritis siswa, serta solusi untuk meningkatkan disposisi berpikir kritis siswa pada pembelajaran matematika di kelas XI IPS pada salah satu SMA di Kota Sungai Penuh Provinsi Jambi. 


\section{METODE PENELITIAN}

Adapun jenis penelitian ini adalah penelitian kualitatif dengan menggunakan pendekatan deskriptif. Pendekatan ini adalah penelitian yang membutuhkan kedalaman analisis secara objektif, dan sistematis, sehingga dihasilkan suatu ketepatan interpretasi. Hal tersebut disebabkan karena hakikat dari suatu fenomena atau gejala bagi penelitian kualitatif adalah totalitas (Margono, 2006). Jenis penelitian ini adalah penelitian lapangan (Field Research) yang berhubungan dengan analisis terhadap disposisi berpikir kritis siswa pada pembelajaran matematika di kelas XI IPS 1 SMA Negeri 5 Sungai Penuh.

Sumber data dalam penelitian ini adalah guru dan siswa. Jenis data dalam penelitian ini adalah data primer dan data sekunder. Data primer merupakan data yang diperoleh dari sumber asli yang memuat informasi atau data tersebut, yakni data yang terhimpun langsung dari guru matematika, siswa dan dokumentasi. Sementara itu, data sekunder merupakan data yang dihimpun dari berbagai sumber tertulis seperti buku, majalah dan dokumen lainnya yang berhubungan dengan penelitian ini, yaitu data yang telah terdokumentasi di SMA Negeri 5 Sungai Penuh.

Informan penelitian adalah orang yang ahli dan memiliki kompetensi yang relevan dengan penelitian yang telah dilaksanakan (Margono, 2006). Adapun teknik penentuan informan penelitian adalah menggunakan teknik purposive sampel, yaitu teknik penentuan informan berdasarkan tujuan dan pertimbangan tertentu (Moleong, 1995). Informan penelitian ini dijabarkan sebagai berikut:

Tabel 1. Informan Penelitian

\begin{tabular}{clc}
\hline No. & \multicolumn{1}{c}{ Informan } & Jumlah \\
\hline 1 & $\begin{array}{l}\text { Guru Matematika Kelas XI SMA } \\
\text { Negeri 5 Sungai Penuh }\end{array}$ & 1 orang \\
\hline 2 & Siswa kelas XI IPS1 & 23 orang \\
\hline & Jumlah & 24 orang \\
\hline
\end{tabular}

Informan dalam penelitian adalah kelas XI IPS1 karena berdasarkan data dan informasi dari guru matematika bahwa kelas XI IPS1 memiliki keragaman tingkat kemampuan matematis, yaitu kemampuan matematika level tinggi, sedang dan rendah. Cara yang dilakukan dalam rangka memperoleh data penelitian disebut dengan teknik pengumpul data. Teknik pengumpulan data dilakukan berdasarkan triangulasi. Triangulasi merupakan teknik analisis keabsahan data dengan menggunakan hal lain di luar data sebagai bahan cross-check atau sebagai pembanding terhadap data (Sugiyono, 2009). Dalam penelitian ini menggunakan triangulasi sumber, teknik dan waktu. 
Penelitian ini menggunakan triangulasi sumber dengan cara pengecekan data yang dihimpun melalui berbagai sumber, yaitu guru, kepala sekolah, dan siswa. Data dari ketiga sumber tersebut dideskripsikan dan dikategorisasikan berdasarkan pandangan yang sama, yang berbeda, serta yang spesifik dari ketiga sumber data tersebut. Penelitian ini menggunakan triangulasi teknik dengan cara pengecekan data kepada sumber yang sama dengan teknik yang berbeda, yaitu data yang dihimpun berdasarkan hasil angket/kuesioner yang diperiksa silang dengan hasil wawancara, observasi, dokumentasi atau catatan lapangan. Penelitian ini juga menggunakan triangulasi waktu dengan cara pengecekan data kepada sumber yang sama tetapi dalam waktu yang berbeda, yaitu saat proses pembelajaran sedang berlangsung pada pagi hari hingga siang hari pada saat pembelajaran telah selesai serta sore hari. Ketiga jenis triangulasi ini digunakan dengan tujuan agar diperoleh suatu keabsahan data dan mengurangi bias dalam penelitian.

Instrumen dalam penelitian merupakan suatu alat atau fasilitas yang digunakan peneliti guna menghimpun data agar pelaksanaan penelitian lebih efisien sehingga memperoleh hasil yang lebih baik, cermat, komprehensif, dan sistematis, sehingga lebih mudah untuk dianalisis dan hasilnya lebih mudah dipahami. Instrumen dalam penelitian ini adalah peneliti sendiri. Pada penelitian kualitatif, merupakan suatu kemustahilan untuk mengadakan suatu penyesuaian terhadap fakta-fakta yang ada di lapangan jika menggunakan suatu alat selain manusia. Setelah masalah selesai, maka dikembangkan suatu alat bantu sederhana yang diharapkan mampu mempermudah peneliti dalam proses pengumpulan data di lapangan.

Prosedur penelitian ini dikelompokkan menjadi tiga tahapan, yaitu tahap persiapan, tahap pelaksanaan, dan tahap penyelesaian sebagai akhir tahapan. Pada tahap pertama yaitu persiapan, jadwal penelitian ditetapkan dan instrumen penelitian dipersiapkan. Pada tahap pelaksanaan untuk mengumpulkan data, peneliti melakukan pengamatan dalam proses pembelajaran matematika yang berlangsung pada kelas XI IPS 1 SMA Negeri 5 Sungai Penuh. Peneliti melakukan wawancara terhadap guru dan siswa yang berhubungan dengan disposisi berpikir kritis siswa pada saat mengikuti proses pembelajaran di kelas. Setelah itu, peneliti memberikan angket disposisi berpikir kritis kepada siswa kelas XI IPS1. Tahap penyelesaian merupakan tahapan peneliti dalam menganalisa data hasil penelitian yang mencakup reduksi data, penyajian data serta penyimpulan data. Angket, pedoman wawancara dan lembaran observasi yang digunakan sudah valid. Validitas merupakan suatu tingkatan yang menunjukkan apakah alat ukur telah sesuai dengan apa yang hendak diukur (Surapranata, 2009). 
Penelitian ini merupakan penelitian deskriptif kualitatif. Pada penelitian kualitatif, data yang muncul mayoritas berupa rangkaian kata. Hal ini sangat berbeda dengan penelitian kuantitatif yang menganalisis data berupa rangkaian angka. Data tersebut tentu saja sangat beragam, sehingga perlu diolah menjadi ringkas dan logis dengan cara yang sistematis. Analisis data kualitatif merupakan upaya yang dilakukan dalam rangka mencari dan menemukan pola, menemukan hal-hal penting yang harus dipahami secara mendalam, serta memutuskan sesuatu yang harus disampaikan kepada orang lain. Analisis data kualitatif ini dilakukan dengan cara bekerja dengan data, mengorganisasikannya serta memilah data sehingga menjadi suatu kesatuan yang dapat dikelola dan disintesis (Iskandar, 2009).

Berdasarkan definisi tersebut dapat diambil kesimpulan yaitu analisis data kualitatif merupakan suatu proses pengorganisasian data yang diperoleh dari lapangan kemudian disortir lalu mempelajarinya, sehingga dapat dikelola dan digali untuk memperoleh suatu informasi yang penting. Pada akhirnya, data tersebut disajikan dengan baik dalam urutan yang sistematis dan logis berdasarkan fakta yang ditemukan di lapangan yang sama sekali tidak dimaksudkan untuk membuktikan suatu hipotesis penelitian. Subyek dalam penelitian ini adalah seluruh siswa kelas XI IPS 1 SMA Negeri 5 Sungai penuh yang berjumlah 23 orang siswa. Penelitian ini telah dilaksanakan pada bulan November 2019.

\section{HASIL DAN PEMBAHASAN}

Angket disposisi berpikir kritis siswa terdiri dari 30 pertanyaan yang memuat 5 indikator disposisi berpikir kritis, yaitu (1) percaya diri, (2) gigih dan tekun, (3) open-minded dan fleksibel, (4) minat dan keingintahuan, (5) monitor dan evaluasi. Angket tersebut diberikan kepada 23 orang siswa kelas XI IPS 1 untuk melihat disposisi berpikir kritis siswa pada pembelajaran matematika. Adapun hasil angket dipaparkan pada Tabel 2.

Tabel 2. Hasil Angket Disposisi Berpikir Kritis 


\begin{tabular}{cccccccc}
\hline $\begin{array}{c}\text { Kode } \\
\text { Siswa }\end{array}$ & SS & S & N & TS & STS & $\begin{array}{c}\text { Jumlah } \\
(\boldsymbol{\%})\end{array}$ & Kesimpulan \\
\hline E-1 & 0 & 18 & 0 & 10 & 2 & 62,67 & Sedang \\
E-2 & 3 & 13 & 1 & 10 & 3 & 62,00 & Sedang \\
E-3 & 9 & 8 & 0 & 10 & 3 & 66,67 & Sedang \\
E-4 & 8 & 9 & 1 & 9 & 3 & 66,67 & Sedang \\
E-5 & 7 & 9 & 1 & 10 & 3 & 64,67 & Sedang \\
E-6 & 12 & 10 & 0 & 7 & 1 & 76,67 & Tinggi \\
E-7 & 10 & 12 & 0 & 8 & 0 & 76,00 & Tinggi \\
E-8 & 3 & 13 & 1 & 10 & 3 & 62,00 & Sedang \\
E-9 & 8 & 11 & 2 & 9 & 0 & 72,00 & Tinggi \\
E-10 & 9 & 12 & 2 & 5 & 2 & 74,00 & Tinggi \\
E-11 & 7 & 10 & 0 & 10 & 3 & 65,33 & Sedang \\
E-12 & 8 & 9 & 1 & 11 & 1 & 68,00 & Sedang \\
E-13 & 9 & 11 & 1 & 7 & 2 & 72,00 & Tinggi \\
E-14 & 5 & 10 & 0 & 10 & 5 & 60,00 & Sedang \\
E-15 & 3 & 10 & 2 & 7 & 8 & 55,33 & Sedang \\
E-16 & 4 & 8 & 2 & 7 & 9 & 54,00 & Rendah \\
E-17 & 5 & 7 & 1 & 8 & 9 & 54,00 & Rendah \\
E-18 & 8 & 7 & 0 & 11 & 4 & 62,67 & Sedang \\
E-19 & 9 & 2 & 2 & 10 & 7 & 57,33 & Sedang \\
E-20 & 7 & 5 & 1 & 10 & 7 & 56,67 & Sedang \\
E-21 & 2 & 6 & 1 & 11 & 10 & 46,00 & Rendah \\
E-22 & 2 & 7 & 3 & 9 & 9 & 49,33 & Rendah \\
E-23 & 1 & 9 & 1 & 8 & 11 & 47,33 & Rendah \\
\hline
\end{tabular}

Dari tabel 2 di atas dapat diperoleh bahwa terdapat 5 orang siswa (22\%) memiliki disposisi berpikir kritis yang tinggi dan 13 orang siswa (56\%) memiliki disposisi berpikir kritis yang sedang. Hal ini menunjukkan adanya proses pembelajaran yang pada umumnya sudah terlaksana dengan baik. Namun, terdapat 5 orang siswa $(22 \%)$ memiliki disposisi berpikir kritis yang rendah. Hal ini dapat diatasi melalui pemberian model pembelajaran yang diduga dapat meningkatkan kemampuan berpikir kritis siswa selama proses pembelajaran, misalnya Pembelajaran Berbasis Masalah (PBM) dan strategi Think Talk Write (TTW) (Sumarmo, Hidayat, Zukarnaen, Hamidah \& Sariningsih, 2012).

Siswa yang memiliki disposisi berpikir kritis akan lebih sensitif terhadap kegiatan berpikir secara kritis, merasa termotivasi untuk berpikir kritis, dan memiliki kemampuan mendasar dalam berpikir kritis walaupun dimasukkan konsep kemampuan dalam unsur disposisinya. Maka pemikir kritis yang baik seharusnya tidak hanya menunjukkan keterampilan kognitifnya saja tetapi juga akan selalu berusaha untuk membekali dirinya dengan sikap disposisi berpikir kritis.

Siswa dengan disposisi berpikir kritis yang tinggi dan sedang akan dapat menyelesaikan setiap persoalan yang diberikan guru selama proses pembelajaran. Selain itu, 
minat dan keingintahuannya terhadap pembelajaran matematika juga akan meningkat. Hal ini sesuai dengan penelitian terdahulu yang telah dilaksanakan oleh Hidayat \& Sari (2019) yang menghasilkan bahwa siswa dengan disposisi berpikir kritis yang tinggi dapat menyelesaikan permasalahan yang diberikan dengan tepat. Kemudian siswa juga dapat memberikan jawaban dengan menggunakan beragam cara penyelesaian. Hasil observasi pelaksanaan pembelajaran di kelas dianalisis berdasarkan langkah-langkah pembelajaran, yaitu pendahuluan, inti dan penutup sebagai berikut:

a. Kegiatan Pendahuluan

Kegiatan ini berlangsung kira-kira selama \pm 20 menit. Guru mengawali kegiatan pembelajaran dengan cara mengucap salam kemudian siswa diminta untuk berdoa secara bersama-sama sebelum memulai proses pembelajaran. Selanjutnya guru mengecek kehadiran siswa yang kemudian dilanjutkan dengan kegiatan memotivasi siswa serta memberikan informasi tentang materi pelajaran yang akan dipelajari atau yang sering disebut literasi.

Literasi yang sering digunakan oleh guru, biasanya dituangkan dalam bentuk gambar atau video dengan menggunakan media infokus/LCD. Misalnya dalam materi Barisan dan Deret, guru biasanya menampilkan gambar kilometer pada kendaraan bermotor, seperti pada gambar berikut:
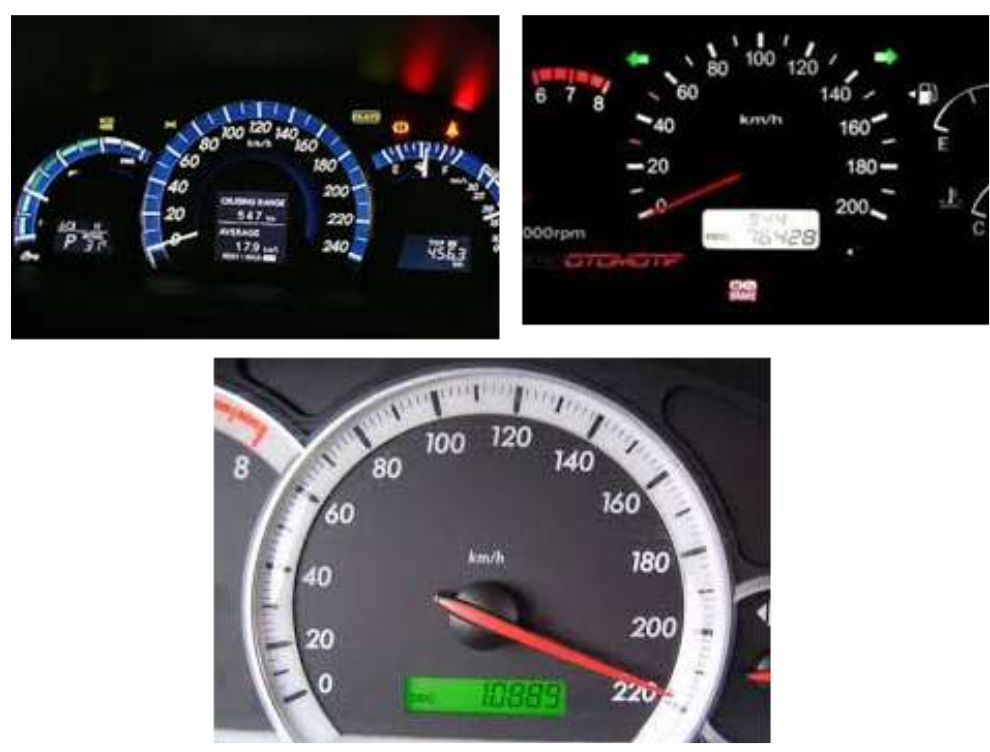

\section{Gambar 1. Kilometer Kendaraan Bermotor}

Berdasarkan Gambar 1 di atas, siswa diminta untuk menerangkan apa yang siswa ketahui tentang gambar dan apa yang siswa amati dari gambar tersebut. Setiap siswa memiliki pandangan dan pengetahuan yang berbeda tentang Gambar 1 dan guru mengarahkan pengetahuan siswa tersebut ke dalam materi pelajaran. Kegiatan guru 
dalam membuka proses pembelajaran tersebut telah sesuai dengan materi yang akan diajarkan. Siswa menyimak dan mendengar penjelasan guru serta mau memperhatikan kegiatan pendahuluan yang disampaikan oleh guru dengan penuh semangat.

b. Kegiatan Inti

Metode ekspositori digunakan oleh guru dalam mengajarkan materi pembelajaran dengan cara menyajikan materi secara interaktif menggunakan media infokus/LCD untuk lebih mempermudah guru menyajikan grafik atau gambar yang dibutuhkan sesuai dengan materi yang sedang dibahas. Selama proses pembelajaran, guru lebih melibatkan siswa untuk berperan aktif dalam kegiatan belajar mengajar dengan cara mempersilakan beberapa orang siswa untuk menyelesaikan soal yang diberikan berkaitan dengan materi yang sedang dibahas. Di mana materi tersebut telah dijelaskan terlebih dahulu oleh guru secara interaktif.

Selama proses pembelajaran sedang berlangsung, guru bertanya sebanyak enam kali kepada enam orang siswa dengan pertimbangan tertentu, seperti dua orang siswa dengan kemampuan matematika rendah, dua orang dengan kemampuan matematika sedang dan dua orang dengan kemampuan matematika tinggi. Terdapat enam orang siswa yang memperoleh kesempatan untuk menjawab pertanyaan dari guru. Selain itu, ada juga beberapa orang siswa yang mengajukan pertanyaan. Guru memberikan penilaian kepada siswa adalah dengan cara memberikan pertanyaan dan memberikan soal latihan yang diselesaikan secara individu di kelas yang kemudian dikumpulkan pada akhir proses pembelajaran.

Salah satu pertanyaan yang diberikan guru terkait materi Barisan dan Deret adalah penemuan rumus Barisan Aritmatika. Siswa berkemampuan rendah sama sekali tidak memiliki ide dalam proses penemuan rumus Barisan Aritmatika. Siswa berkemampuan rendah menganggap rumus tersebut sudah ada disepakati sejak dahulu oleh para ahli Matematika. Hal ini menunjukkan siswa berkemampuan rendah tidak kritis sebab tidak memiliki rasa ingin tahu terhadap asal muasal rumus tersebut. Hal ini menunjukkan bahwa siswa berkemampuan rendah memiliki disposisi berpikir kritis yang rendah. Sementara itu, siswa berkemampuan sedang memiliki minat dan rasa ingin tahu terkait dengan penemuan rumus Barisan Aritmatika. Namun mereka tidak memiliki rasa percaya diri dalam proses penemuan rumus tersebut. Siswa berkemampuan sedang kurang tekun dan gigih dalam mencoba berbagai cara dalam rangka menemukan rumus Barisan Aritmatika. Di sisi lain, siswa berkemampuan tinggi memiliki semangat dan motivasi yang tinggi dalam mencoba menemukan rumus Barisan Aritmatika. Siswa 
berkemampuan tinggi memiliki pikiran yang luas dan terbuka dalam mencoba segala macam kemungkinan sehingga rumus tersebut dapat ditemukan. Bahkan siswa berkemampuan tinggi mampu menemukan rumus tersebut dengan lebih dari satu cara. Hal ini menunjukkan bahwa siswa berkemampuan tinggi memiliki sikap yang tekun, gigih, open-minded, minat serta rasa ingin tahu yang tinggi yang bersesuaian dengan indikator disposisi berpikir kritis.

Pada setiap pengerjaan tugas yang dilakukan oleh siswa, guru berperan sebagai fasilitator. Guru membimbing dan mengarahkan siswa untuk dapat menyelesaikan permasalahan yang sedang dikerjakan. Guru juga memberikan penilaian terhadap aktivitas siswa selama proses pembelajaran, khususnya kepada siswa yang bersedia menyelesaikan permasalahan yang diberikan di depan kelas.

Terdapat dua orang siswa yang mengganggu pelajaran, yaitu membuat keributan di kelas. Guru memberikan teguran halus kepada siswa tersebut kemudian menasihati dan memotivasinya. Jika masih tidak terdapat perubahan dari siswa tersebut, guru kemudian memberikan teguran keras dengan cara memberikan hukuman berupa pengurangan skor atau nilai. Untuk itu, guru selalu mengingatkan siswa agar tidak membuat keributan selama proses pembelajaran sedang berlangsung. Selain itu, guru juga memberikan beberapa teguran kepada siswa yang selalu membuat alasan ingin ke toilet agar keluar dari kelas.

Secara umum, siswa menyimak materi yang diajarkan guru. Siswa fokus kepada penjelasan guru dan memberikan respons terhadap pertanyaan yang diajukan oleh guru. Namun, masih ada beberapa orang siswa yang kurang fokus selama proses pembelajaran sedang berlangsung. Hal ini tampak pada saat mereka ditanya, mereka tidak mampu menjawab pertanyaan dengan baik. Hal ini kemudian di-cross-check dengan hasil wawancara, ternyata siswa tersebut sedang mengalami gangguan kesehatan namun tidak begitu serius. Kegiatan inti ini berlangsung selama \pm 60 menit. Berdasarkan hasil observasi, guru berusaha menciptakan suasana pembelajaran yang serius tetapi santai. Proses pembelajaran berlangsung secara kondusif. Guru menyapa dan memotivasi siswa saat siswa mulai merasa bosan. Guru memberikan humor ringan dan bersikap hangat kemudian memberikan ice breaking sehingga siswa menjadi bersemangat kembali untuk mengikuti proses pembelajaran.Guru tidak menemukan masalah yang berarti dalam mengajar meskipun berada pada kelas yang heterogen. Meskipun tidak seluruh siswa berperan aktif, cerdas dan cepat tanggap dalam memahami materi pelajaran, siswa tetap berpikiran positif mereka akan tetap dapat memahami materi dengan baik melalui 
kebiasaan dalam mengerjakan soal latihan. Masalah-masalah ringan yang terjadi dapat segera diatasi oleh guru sehingga proses pembelajaran dapat berjalan dengan optimal.

c. Kegiatan Penutup

Kegiatan penutup berlangsung selama \pm 10 menit. Sebelum mengakhiri proses pembelajaran, guru memberikan informasi terkait jam pelajaran yang akan habis. Guru menyarankan siswa untuk segera menyelesaikan tugas yang telah diberikan. Guru juga mengingatkan siswa agar mengulang kembali materi yang telah dipelajari di rumah. Pada akhir kegiatan pembelajaran, guru bersama siswa menyimpulkan seluruh materi yang telah dibahas kemudian guru memberikan pekerjaan rumah yang akan dibahas pada pertemuan berikutnya.

Berdasarkan analisis hasil observasi tersebut dapat disimpulkan bahwa guru, siswa, situasi dan kondisi kelas merupakan faktor penting yang sangat berpengaruh terhadap keberhasilan pembelajaran di kelas. Guru merupakan faktor yang paling berpengaruh untuk memicu disposisi siswa dalam berpikir kritis. Guru mampu menciptakan suasana belajar yang tenang, kondusif dan terarah dengan memberikan kebebasan kepada siswa untuk bertanya, memberikan gagasan, pendapat dan ide dalam belajar. Siswa termotivasi selama dalam belajar matematika. Hal ini mengindikasikan bahwa siswa memiliki suatu sikap positif (disposisi) yang diikuti dengan kegiatan berpikir kritis. Hal tersebut tentu berpengaruh terhadap kesuksesan pembelajaran matematika. Kepala Sekolah sangat mendukung terciptanya kenyamanan siswa dan guru dalam proses belajar mengajar baik di dalam kelas maupun di luar kelas. Situasi dan kondisi kelas serta lingkungan sekolah juga memberikan pengaruh yang positif terhadap kesuksesan kegiatan pembelajaran. Kondisi kelas dan lingkungan sekolah sangat nyaman dan asri. Ruang kelas juga dilengkapi dengan fasilitas pendukung proses pembelajaran yang baik seperti media pembelajaran elektronik yang memadai. Hal ini dapat menciptakan disposisi berpikir kritis bagi siswa.

Banyak faktor yang mempengaruhi disposisi berpikir kritis, di antaranya adalah kurangnya kemampuan dasar siswa dalam perhitungan matematika, sehingga menyebabkan siswa sulit dalam menyelesaikan permasalahan yang diberikan guru yang berakibat rendahnya kecenderungan siswa untuk belajar matematika. Hal ini sesuai dengan penelitian yang dilakukan oleh Nasution (2018) yang menyatakan bahwa siswa kurang memiliki persiapan awal sebelum memulai kegiatan pembelajaran,yang terdiri dari minimnya pengetahuan awal yang dimiliki siswa yang berkaitan dengan materi prasyarat terutama yang 
berkaitan dengan kemampuan perhitungan dasar matematika sehingga hal inibias menjadi faktor penghambat untuk mengikuti materi pelajaran berikutnya. Untuk mengatasi hal tersebut, guru harus terlebih dahulu mengulang kembali materi pembelajaran terdahulu guna membangkitkan ingatan siswa untuk menunjang kesuksesan pembelajaran materi yang akan dipelajari. Hal ini tentu saja membutuhkan kemampuan pedagogik guru dalam manajemen waktu.

Strategi yang digunakan guru dalam pengelolaan kelas merupakan salah satu faktor utama dalam membangkitkan sikap disposisi berpikir kritis pada siswa. Dalam pengelolaan kelas, guru harus lebih memvariasikan strategi dan media pembelajaran relevan yang bersesuaian dengan kebutuhan materi dan kebutuhan siswa serta perkembangan teknologi informasi. Situasi kelas yang meningkatkan motivasi belajar siswa akan menumbuhkan minat dan motivasi siswa dalam pembelajaran. Hal ini juga dikemukakan oleh Nasution (2018) bahwa guru dapat menerapkan berbagai strategi pembelajaran yang mampu memicu disposisi berpikir kreatif siswa. Keadaan lingkungan sekitar sekolah, suasana ruang belajar serta ketersediaan sarana dan prasarana pendukung kegiatan pembelajaran seharusnya dijaga dan dipelihara keberadaannya sehingga dapat menumbuhkan sikap positif siswa dalam belajar matematika di kelas.

Berdasarkan hasil analisis terhadap wawancara kepada guru ditemukan bahwa ada beberapa faktor yang mempengaruhi disposisi berpikir kritis siswa pada pembelajaran matematika, di antaranya adalah latar belakang siswa yang memang kurang dalam hitungan atau rumus-rumus yang persepsi mereka memang sulit dan membosankan. Selain itu, metode yang digunakan guru pada proses pembelajaran memang seharusnya bervariasi bersesuaian dengan kebutuhan materi dan tentunya sesuai dengan perkembangan zaman.

Apabila cara penyampaian guru yang melatarbelakangi kecenderungan siswa untuk sulit memahami matematika, maka guru dapat memanfaatkan media dan sarana lainnya yang dapat menunjang pembelajaran agar lebih terlihat menarik dan memotivasi siswa untuk belajar matematika. Guru juga sebaiknya memperoleh fasilitas pelatihan dan penyegaran kompetensi guru dalam mengajar, sehingga guru mampu mengikuti perkembangan dunia pendidikan dengan menggunakan metode dan teknik kekinian relevan yang lebih efektif dan efisien jika diterapkan dalam proses belajar-mengajar.

Guru mata pelajaran matematika pada kelas yang diteliti menyatakan bahwa untuk dapat menumbuhkan disposisi (sikap) berpikir kritis siswa pada pembelajaran matematika memang tidak semudah dibandingkan mata pelajaran MIPA yang lain. Matematika 
merupakan pembelajaran yang sifatnya mengikat pengetahuan atau suatu konsep dengan konsep lainnya, yang sering disebut dengan materi prasyarat.

Untuk dapat meningkatkan disposisi berpikir kritis siswa, salah satu caranya adalah dengan memvariasikan strategi yang dilakukan oleh guru selama proses belajar-mengajar. Guru harus lebih kreatif dan inovatif dalam menyajikan materi pelajaran, baik itu dengan memanfaatkan media teknologi informasi dan komunikasi (TIK) yang sedang berkembang saat ini.Perlunya pengelolaan kelas yang ideal dan inovatif membuat suasana kelas yang nyaman sebagai lingkungan pembelajaran akan membuat rasa nyaman siswa untuk belajar. Selain itu, strategi dan media pembelajaran inovatif akan dapat memberikan antusiasme siswa dalam pembelajaran.

Guru matematika juga telah dibekali oleh beberapa pelatihan dan diklat, seperti program Peningkatan Kompetensi Pembelajaran (PKP) bagian dari Program Pengembangan Keprofesian Berkelanjutan (PKB). Di mana PKP merupakan salah satu program pemerintah sebagai upaya meningkatkan mutu kompetensi guru dalam pembelajaran bagi guru sasaran (GS). Dengan adanya program PKP diharapkan semua guru dapat meningkatkan kinerja dan kompetensinya untuk mendidik siswa dalam rangka menumbuhkembangkan disposisi berpikir kritis siswa.

Wawancara kepada siswa dengan disposisi berpikir kritis rendah menyimpulkan kurangnya rasa keingintahuan siswa terhadap pembelajaran matematika karena matematika dianggap sulit. Selain itu, kurangnya minat siswa dalam belajar matematika diakibatkan oleh minimnya kemampuan dasar matematis siswa khususnya dalam perhitungan dasar matematika. Siswa juga merasa bahwa guru terlalu terburu-buru dalam mengajar sementara siswa belum memahami materi sepenuhnya.

\section{KESIMPULAN}

Berdasarkan hasil analisis data dan pembahasan, kesimpulan penelitian ini adalah sebagai berikut:

1. Disposisi berpikir kritis siswa pada pembelajaran matematika di kelas XI SMA Negeri 5 Sungai Penuh pada umumnya berada pada kategori sedang. Jumlah siswa yang memiliki disposisi berpikir kritis yang tinggi tidak berbeda dengan jumlah siswa yang memiliki disposisi berpikir kritis yang rendah. Artinya proses belajar-mengajar pada umumnya sudah baik. Temuan-temuan mengenai disposisi berpikir kritis siswa dapat digunakan untuk mencari upaya perbaikan pembelajaran matematika berikutnya. 
2. Faktor-faktor yang mempengaruhi disposisi berpikir kritis siswa pada pembelajaran matematika di kelas XI SMA Negeri 5 Sungai Penuh, di antaranya kurangnya kemampuan dasar siswa dalam perhitungan matematika, sehingga menyebabkan siswa sulit untuk menyelesaikan permasalahan yang diberikan oleh guru yang berakibat rendahnya kecenderungan siswa untuk belajar matematika. Selain itu, strategi yang dilakukan oleh guru dalam pengelolaan kelas juga menjadi salah satu faktor yang akan mempengaruhi disposisi berpikir kritis siswa. Dalam mengelola kelas guru harus lebih memvariasikan strategi dan media pembelajaran sesuai dengan kebutuhan materi dan kebutuhan siswa serta perkembangan teknologi informasi. Situasi kelas yang meningkatkan motivasi belajar siswa akan menumbuhkan semangat dan minat siswa dalam pembelajaran.

3. Solusi untuk meningkatkan disposisi berpikir kritis pada pembelajaran matematika di kelas XI SMA Negeri 5 Sungai Penuh adalah perlunya pengelolaan kelas yang ideal dan inovatif membuat suasana kelas yang nyaman sebagai lingkungan pembelajaran akan membuat rasa nyaman siswa untuk belajar. Selain itu, strategi dan media pembelajaran yang inovatif akan memberikan rasa antusias siswa dalam pembelajaran. Guru mata pelajaran matematika sebaliknya dibekali oleh beberapa pelatihan dan diklat, seperti Peningkatan Kompetensi Pembelajaran (PKP) dan Program Pengembangan Keprofesian Berkelanjutan (PKB).

\section{DAFTAR PUSTAKA}

Arifin, M. (2010). Filsafat Pendidikan Islam. Jakarta: Bumi Aksara.

Chotimah, S., Bernard, M., \& Wulandari, S. M. (2018). Contextual approach using VBA learning media to improve students' mathematical displacement and disposition ability. In Journal of Physics: Conference Series (Vol. 948, No. 1, p. 012025). IOP Publishing.

Hamdani. (2011). Dasar-Dasar Kependidikan.Bandung: Pustaka Setia.

Hendriana, H., Sumarmo, U., \& Rohaeti, E. E. (2013). Kemampuan Komunikasi Matematik serta Kemampuan dan Disposisi Berpikir Kritis Matematik. Delta-Pi: Jurnal Matematika Dan Pendidikan Matematika, 2(1).

Hidayat, W., \& Sari, V. T. A. (2019). Kemampuan Berpikir Kritis Matematis dan Adversity Quotient Siswa SMP. Jurnal Elemen, 5(2), 242-252.

Iskandar. (2009). Metode Penelitian Pendidikan dan Sosial ,Kuantitatif dan Kualitatif Jakarta: Gaung Persada Press.

Ismunandar, D. (2016). Pembelajaran Bermuatan Disposisi Matematika pada Kelas X Program IPS. Mathline: Jurnal Matematika dan Pendidikan Matematika, 1(2), 70-82

Jalaluddin \& Abdullah, I. (2010). Filsafat Pendidikan. Jakarta: Gaya Media Pratama.

Mahmudi, A., \& Saputro, B. A. (2016). Analisis Pengaruh Disposisi Matematis, Kemampuan Berpikir Kreatif, dan Persepsi pada Kreativitas terhadap Kemampuan Pemecahan Masalah Matematis. Mosharafa: Jurnal Pendidikan Matematika, 5(3), 205212. 
Margono.(2006), Metodologi Penelitian Pendidikan. Jakarta: Rineka Cipta.

Moleong, L. J. (1995) Metodologi Penelitian Kualitatif. Bandung: Remaja Rosdakarya.

Nasution, E. Y. P. (2016). Analisis terhadap DisposisiMatematis Siswa SMK pada Pembelajaran Matematika. Logaritma: Jurnal Ilmu-ilmu Pendidikan dan Sains, 4(01), 77-95.

- (2018). Analisis Terhadap Disposisi Berpikir Kreatif Siswa Pada Pembelajaran Matematika. Edumatika: Jurnal Riset Pendidikan Matematika, 1(1), 4455.

Nopriana, T. (2015). Disposisi Matematis Siswa melalui Model Pembelajaran Geometri Van Hiele. FIBONACCI: Jurnal Pendidikan Matematika dan Matematika, 1(2), 80-94.

Sugiyono. (2009). Metode Penelitian Pendidikan Pendekatan Kuantitatif, Kualitatif dan $R \& D$, Bandung: Alfabeta.

Suherman, E. (2003). Strategi Pembelajaran Matematika Kontemporer. Bandung: Pustaka Setia.

Sumarmo, U., Hidayat, W., Zukarnaen, R., Hamidah, M., \& Sariningsih, R. (2012). Kemampuan dan Disposisi Berpikir Logis, Kritis, dan Kreatif Matematik (Eksperimen terhadap Siswa SMA Menggunakan Pembelajaran Berbasis Masalah dan Strategi ThinkTalk-Write). Jurnal Pengajaran MIPA, 17(1), 17-33.

Surapranata, S.(2009). Analisis, Validitas, Reliabilitas dan Interpretasi Hasil Tes Implementasi Kurikulum 2004. Bandung: PT Remaja Rosdakarya.

Susanti, D. W., \& Rohmah, F. A. (2012). Efektivitas musik klasik dalam menurunkan kecemasan matematika (math anxiety) pada siswa kelas XI. HUMANITAS (Jurnal Psikologi Indonesia), 8(2), 129-142.

Tümkaya, S., Aybek, B., \& Aldaş, H. (2009). An Investigation of University Students' Critical Thinking Disposition and Perceived Problem Solving Skills. Eurasian Journal of Educational Research (EJER), (36).

Ulger, K. (2018). The effect of problem-based learning on the creative thinking and critical thinking disposition of students in visual arts education. Interdisciplinary Journal of Problem-Based Learning, 12(1).

Yunarti, T. (2011). Pengaruh Metode Socrates terhadap Kemampuan dan Disposisi Berpikir Kritis Matematis Siswa SMA. Disertasi tidak diterbitkan. Bandung: UPI. 